\title{
Hysterotomy of a dairy cow with long-time macerated foetus - a case report
}

\author{
Michal Dolník*, Marián Kadaši, Ján Pošivák, Milan Tóth, \\ and Pavol Mudroň
}

Clinic of Ruminants, University of Veterinary Medicine and Pharmacy in Košice, Slovakia

\begin{abstract}
DOLNÍK, M., M. KADAŠI, J. POŠIVÁK, M. TÓTH, P. MUDROŇ: Hysterotomy of a dairy cow with long-time macerated foetus. Vet. arhiv 89, 903-912, 2019. ABSTRACT

A Simmental dairy cattle, aged seven years old, was presented with a history of foul smelling discharge from the external genitalia. According to the history, during the latest parturition the foetus had died in the uterus and was partially removed, but parts of the foetus had remained in the uterus for the following fourteen months. Gynaecological examination confirmed an open cervix. Trans-rectal palpation and ultrasound examination revealed extension, thickening and tension of the uterine wall and the presence of putrid parts of the foetus in the uterus. Attempts to remove the foetus by prostaglandin injections were futile, hence left side low flank hysterotomy was performed under cranial epidural anaesthesia and local infiltration anaesthesia. The foetal bones were removed and the other pathological contents were also removed. The cow gained weight and could subsequently be sent for slaughter. It was concluded that left flank hysterotomy can be useful for removal of macerated foetus from cows.
\end{abstract}

Key words: dairy cattle; hysterotomy; surgical approach; maceration

\section{Introduction}

Maceration is the disintegration of a foetus within the uterus (RAUTELA et al., 2016). The reason for the non-delivery of a dead foetus could be a partially dilated cervix, uterine inertia, or the abnormal presentation of a fairly dry foetus which causes it to be retained in the uterus (PRAVEEN and NAIDU, 2015). The process of maceration can occur only after the formation of foetal bones and has been observed in all species of animals (KRISHNAKUMAR et al., 2008).

Unlike mummification, which takes place in a closed uterus without access to bacterial contamination, in maceration emphysema and maceration of the foetus occur after the

*Corresponding author:

MVDr. Michal Dolník, Clinic of Ruminants, University of Veterinary Medicine and Pharmacy in Košice, Komenského 73, 04181, Košice, Slovakia, Phone: +42 1948158 026, E-mail: michal.dolnik890@gmail.com 
death of the foetus in the uterus, with an incompletely closed cervix. As a result there is contact with the outside environment, followed by invasion of bacteria from the vagina (DROST, 2007; BEKELE et al., 2016). Following bacterial invasion of the uterus there is putrefaction and autolysis, and the soft tissues are digested, leaving a mass of foetal bones along with pus within the uterus (DEORI et al., 2012; BHATTACHARYYA et al., 2015). However, the bones cannot be easily expelled by the animal on its own through an inadequately open cervix. Under such circumstances the disintegrated foetal parts and bones may be retained in the uterus for prolonged periods, necessitating surgical removal (KUMAR et al., 2013a). This case describes the diagnosis, treatment options, anaesthetic management, and surgical approach in a case of a cow with a long-term macerated foetus.

\section{Case presentation}

A Simmental dairy cattle, aged seven years (after the third pregnancy), was admitted with a foul smelling discharge from the external genitalia. During a previous parturition fourteen months earlier the cow had had dystocia and the foetus died. Only the forelimbs and head of foetus were removed by the attending veterinarian. The other parts of the foetus remained in the uterus. The cow was kept for the following fourteen months to recover and gain weight to be sent to the slaughter house and as such was not monitored closely. However, the cow suffered permanently from a slight purulent discharge from a vulva. Therefore, at the end of this period there was an attempt to remove the remains of the foetus with prostaglandins, but the result was unsuccessful.

General clinical examination revealed that the general condition of the animal was good. Blood was collected from the jugular vein for routine analysis, which is practised in every patient in our clinical laboratory. The blood was analysed for evaluation of the haematological (Hb, Er, Hk, Le, MCV on animal blood counter BC-2800 Vet, Mindray, China) and biochemical (glucose, cholesterol, TG, BHB, TB, Albumin, creatinine, urea, AST, GGT, AF, LDH, CPK, P on spectrophotometric automatic analyser ALIZÉ, Lisabio, France; $\mathrm{Ca}, \mathrm{Mg}, \mathrm{Na}, \mathrm{K}, \mathrm{Cu}, \mathrm{Fe}, \mathrm{Zn}$ on atomic absorption analyser with flame Aanalyst 100, Perkin Elmer; NEFA,TL, TIg, Bi on spectrophotometric analyser SPECORD 210/PLUS, Analytik Jena, Germany) parameters. The results of the analysis did not show significant differences in the selected parameters. Gynaecological examination confirmed an open cervix, dilated about 1 - 2 fingers in diameter, with a foul smelling purulent discharge. No foetal parts could be found in the cervix. Trans-rectal examination revealed extension, thickening and tension of the uterine wall. Trans-rectal sonographic examination revealed the presence of corpus luteum on the left ovary and a pathological content, consisting of hyperechogenic parts of the foetal bones and hypoechogenic liquid content, with more echogenous pus in the uterus. The case was diagnosed as foetal maceration. 
First, hormonal therapy to expel the remnants of the foetus from the uterus was performed. $2 \mathrm{~mL}$ of cloprostenol (Oestrophan $0.25 \mathrm{mg} / \mathrm{mL}$, Bioveta a.s., Czech Republic) was administered intramuscularly. The expulsion should have occurred within 36 hours. However, this measure was unsuccessful, so a surgical method was chosen - hysterotomy.

Feed was restricted for 24 hours prior to surgery. The cow had free access to water. Anaesthesia was started with sedation using 2\% xylazine $(0.1 \mathrm{mg} / \mathrm{kg}$ ) (Xylariem $20 \mathrm{mg}$ / $\mathrm{mL}$, Ecuphar, Germany) applied into the neck muscle followed by epidural anaesthesia with $2 \%$ procaine $(150 \mathrm{~mL}$ ) (Procamidor $20 \mathrm{mg} / \mathrm{mL}$, Richter pharma, Austria), which was injected between the first and second caudal vertebrae. The cow was restrained in right lateral recumbency. Additionally, local infiltration anaesthesia was infused in the area of the incision, by injecting 2\% procaine (40 mL) (Procamidor $20 \mathrm{mg} / \mathrm{mL}$, Richter pharma, Austria).

The animal was prepared for aseptic surgery as described previously (KUMAR et al., 2013a). The left ventral abdominal wall was shaved, scrubbed with warm water and iodine soap solution, and then disinfected with a $70 \%$ alcohol and $10 \%$ iodine solution. The site of incision was then draped with sterile drape.

The incision was made on the left, central side of the abdomen, approximately 25 $\mathrm{cm}$ above the skin fold of the stifle, and continued in an oblique caudo-ventrocranial direction. The total length of the incision was about $35 \mathrm{~cm}$. After incision of the skin, subcutaneous tissue, muscles and peritoneum, the, uterus was exteriorized outside the surgical wound. The exposed part of the uterus was draped with sterile drape and sealed off from the rest of the organs.

The uterine horn was opened with an incision in the dorsal part of the region with the largest curvature. During the incision, the liquid content poured out from the uterine horn. In addition to the liquid contents present in the uterus, we found the bones of the macerated foetus (Fig. 1 and 2) which were then removed manually. At this point extreme care was taken to minimize contamination of the abdominal cavity. There were two surgeons performing this operation, one of which was responsible for the sterility and hygiene of the organs and tissues. The second surgeon was responsible for controlling contamination and removal of the content such as bones and purulent discharge. Subsequently, the uterine lumen was repeatedly lavaged using large volumes of 5\% iodine solution (1500 $\mathrm{mL}$ ) and then 3 antibiotic boluses (Fatroximin, Fatro, Italy) were inserted into the uterine lumen. Both surgeons re-scrubbed and changed to new gloves once the contaminated content had been removed.

The uterine incision was sutured in two layers using a continuous pattern by Cushing with absorbable material. Prior to repositioning of the uterine horn back in the abdominal cavity, the uterine surface was washed with $5 \%$ iodine solution $(500 \mathrm{~mL})$ and then inserted back into the abdominal cavity. 
M. Dolník et al.: Hysterotomy of a dairy cow with long-time macerated foetus

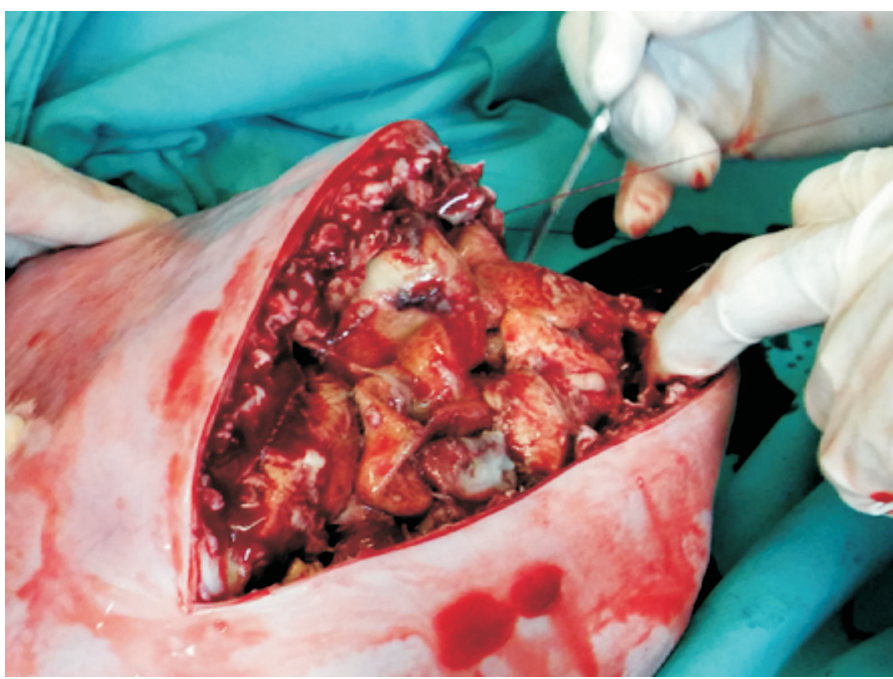

Fig. 1. Incision of the uterus with visible pathological content. The uterine wall was found to be heavily thickened (up to $3 \mathrm{~cm}$ ).

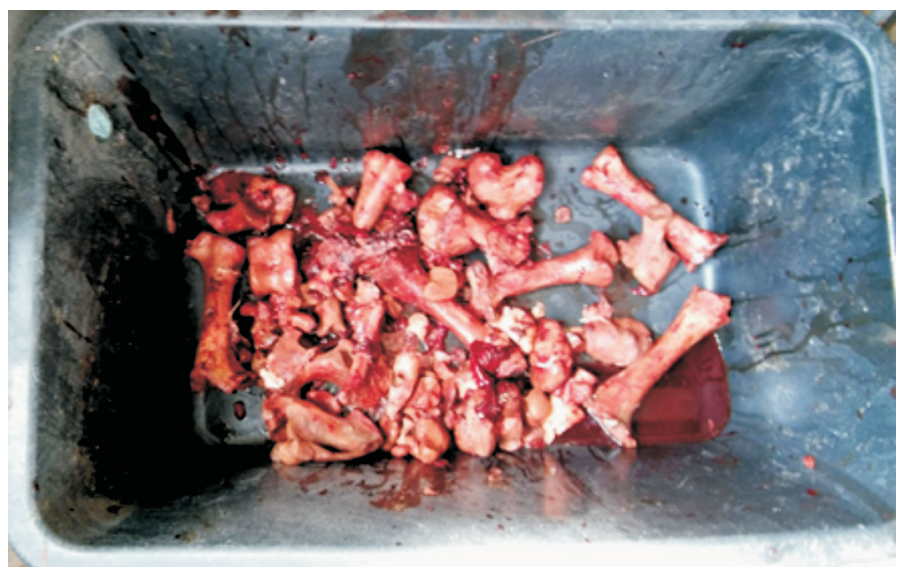

Fig. 2. Remnants of the macerated foetus, which were removed from the uterus. The head and forelimbs were missing, because they had been removed by a local veterinarian on the farm 14 months before. 
The abdominal wall was sutured in three layers, as per the standard procedure. Subsequently the surgical wound was cleaned with $5 \%$ iodine solution $(50 \mathrm{~mL})$ and sprayed with an antibiotic spray. The surgical wound was covered with gauze, which was changed every three days for ten days post-operatively. The antimicrobial drug therapy consisted of ceftiofur $(1 \mathrm{mg} / \mathrm{kg}$ once a day for ten days i.m., (Cevaxel-RTU, Ceva Sante Animale, Libourne, France). Inflammation and pain management was performed using a reduced dose of ketoprofen $(3 \mathrm{mg} / \mathrm{kg}$ once a day for three days i.m., Rifen, Richter pharma AG, Austria).

Healing of the surgical wound and recovery of the animal were without complications. The stitches were removed 14 days after surgery and the cow was sent back to the farm. Her general health condition was not affected. The cow gained weight and was subsequently sent for slaughter.

\section{Discussion}

Prolonged maceration and putrefaction of a foetus is a process that often affects the general status of the affected animal (DROST, 2007). In this case, the process was localized for 14 months in the uterus, but the general health status of the animal was not affected. However, the uterine wall was found to be heavily thickened (up to $3 \mathrm{~cm}$ ). The most severe damage was to the endometrium. This was previously described by BHATTACHARYYA et al. (2015). Both the uterus and cervix were affected by the purulent discharge. Additionally, all the basic characteristics of the cervix, such as elasticity, contractility and its tone, were lost. As a result of these changes, the cervix structure was disrupted and it remained open. Although the surgery was successful, this cow could no longer be used for reproduction due to the uterine damage. As such, it was only important to remove the pathological contents from the uterus so that the cow could be sent for slaughter.

Macerated contents may be evacuated from the uterus using several different methods. If the cervix is sufficiently dilated, it is possible to remove the foetus manually (RAUTELA et al., 2016). The most conservative method, if the cervix is not sufficiently dilated, is the administration of prostaglandins. They lyse the corpus luteum and increase uterine contractions (PUROHIT and GAUR, 2011). The use of prostaglandins for treatment of retained contents has become a routine and often successful method (KUMARESAN et al., 2013). However, there are also reported cases in which the animal did not respond to therapy with prostaglandins (LEFEBVRE et al., 2009). In other cases, after releasing the cervix, only the liquid content is excluded from the uterus, but the foetal bones are detained and it is recommended that they be removed manually, as described by BURNS and CARD (1998). In our case, the therapy using prostaglandins failed and the cervix remained only partially dilated. Therefore, it was not possible to remove the bones 
manually or use any nother method, such as fetotomy, because there was a very limited degree of opening of the cervix for handling of fetotomy equipment (WERMUNT, 2008).

The last option was a hysterotomy. It should be assessed as the last resort due to the high risk of contamination of the abdominal cavity with pathological content and subsequent peritonitis (PUROHIT, 2012). The presence of an emphysematous foetus in the uterus, according to some authors, is a contraindication for this surgical procedure and there can be no doubt that this procedure carries a considerably increased risk to the survival and productivity of the cow, when compared with a caesarean section carried out to remove a live foetus (SCHULTZ et al., 2008). However, according to many authors (DALE et al., 2013; BHATTACHARYYA et al., 2015), surgical removal of macerated contents is the best option for the cow, while future fertility is always doubtful. The authors NEWMAN and ANDERSON (2005) reported that less than $25 \%$ of cows return to breeding.

Although in the present case the general status of the animal was not affected, changes in the uterus were irreversible due to the long-term exposure to the pathological conditions. The extent of these changes led us to decide to remove the foetal remnants surgically. The challenge of performing a successful hysterotomy is often directly related to the proper placement of the incision into the abdominal cavity (CHANDORE et al., 2013). Various incisional methods have been described by many authors (KUMAR et al., 2013b; CHANDORE et al., 2013; MAHESH et al., 2015). Due to the high risk of contamination and subsequent peritonitis, the most common surgical approaches for removal of the macerated foetus are performed in lateral recumbency. However, there have also been cases reported of surgery being performed on standing animals (PRAKASH et al., 2016). WERMUNT (2008) described two surgical approaches on an animal in lateral recumbency - ventrolateral and low-flank.

Probably the most frequent surgery on the abdominal cavity is the left ventrolateral oblique approach that multiple authors (SCHOENFELDER and SOBIRAJ, 2006; DALE et al., 2013; ALFARIS et al., 2014) have described as the most appropriate method for easier exteriorization of the contaminated uterus and safer evacuation of the pathological content. The advantage of the left ventrolateral oblique method is that intestinal loops do not enter into the operation wound, which can happen especially with a caudal paramedian incision, and also an incision from the right side, as was described by CHANDORE et al. (2013).

The ventrolateral oblique approach to the abdominal cavity could not be used in our case because the uterus containing pathological content was not as large as it would be in the later stages of pregnancy, or as a uterus with a more recently macerated foetus. In our case, the uterus was located in the middle of the abdominal cavity. Therefore, to avoid complications in removing the contents of the uterus, and the development of peritonitis, 
we chose an incision in the middle of the abdominal wall with the so-called low-flank approach (Fig. 3). The incision was performed obliquely in a caudo-ventrocranial direction. This incision location leads to easier access and exteriorization of the uterus (WERMUNT, 2008), thus minimising the risk of peritonitis, and it also provides better conditions for wound healing and removal of stitches post operatively. A hysterotomy of the uterus with a macerated foetus usually has a poor prognosis. BOUCHARD et al. (1994) published that only six out of sixteen cows with emphysematous foetus survived a caesarean section.

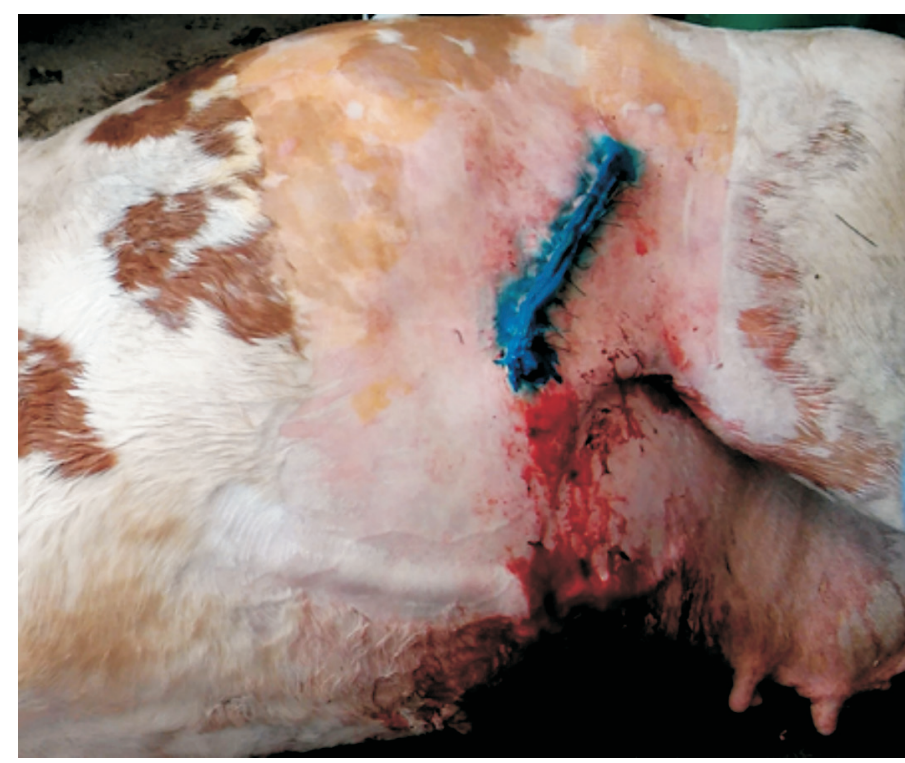

Fig. 3. Localization of the low-flank surgical approach

In conclusion, according to our best knowledge, it is not common to find a case with long-time intrauterinal putrefaction of a foetus without signs of pathological changes to general health status. Moreover, the blood parameters analysed showed no significant changes. On the basis of the confirmed pathological content we decided for surgical intervention. When choosing a suitable approach to the abdominal cavity it is necessary to take a variety of factors into account, based on the history and clinical examination of the individual patient. The low-flank approach method is just one of several possibilities for entering the abdominal cavity. It is our belief that it can offer an alternative to euthanasia in cases where it is impossible to remove an emphysematous foetus using more conservative methods, such as fetotomy or a standard ventrolateral approach. 
M. Dolník et al.: Hysterotomy of a dairy cow with long-time macerated foetus

\section{Acknowledgements}

This work was supported by the Slovak Research and Development Agency under the contract No. APVV0701-11.

\section{References}

ALFARIS, A. A. A., A. T. FAHAD, J. B. HASSAN (2014): Comparison between rolling and surgical treatment of uterine torsion in buffaloes (Bubalis bubalis) in Basrah province. J. Vet. Med. Anim. Health 6, 66-68.

DOI: $10.5897 /$ jvmah2013.0238

BEKELE, N., M. ADDIS, N. ABDELA, V. M. AHMED (2016): Pregnancy diagnosis in cattle for fertility management: A Review. Glob. Vet. 16, 355-364.

DOI: 10.5829/idosi.gv.2016.16.04.103136

BHATTACHARYYA, H. K., S. A. DAR, M. R. FAZILI (2015): Fetal maceration in crossbred Holstein Friesian heifer: a case report. Int. J. Vet. Sci. Res. 1, 1-4.

DOI: 10.18488/journal.110/2015.1.1/110.1.1.4

BOUCHARD, E., D. DAIGNEAULT, D. BELANGER, Y. COUTURE (1994): Cesarians on dairy cows: 159 cases. Can. Vet. J. 35, 770-774 (in French).

BURNS, E. T., E. C. CARD (1988): Fetal maceration and retention of fetal bones in a mare. J. Am. Vet. Med. Assoc. 217, 878-880.

DOI: $10.2460 /$ javma.2000.217.878

CHANDORE, G. G., P. S. MESHARE, V. M. INGAWALE (2013): Comparative evaluation of different surgical approaches of caesarean section in buffaloes under field conditions. Buffalo Bull. 32, 327-334.

DOI: $10.14456 / \mathrm{ku}-$ bufbu. 2013.45

DALE, H., E. HAYES, A. DE KRUIF (2013): Case study: the use of a salvage (low flank) caesarean section to remove an emphysematous calf. Livestock 18, 175-178.

DOI: 10.12968/live.2013.18.5.175

DEORI, S., D. BHUYAN, D. KALITA, K. D. SARMA (2012): Management of foetal maceration in a doe carrying twin. Indian. J. Anim. Sci. 33, 109-110.

DROST, M. (2007): Complications during gestation in the cow. Theriogenology 68, 487-491. DOI: $10.1016 /$ j.theriogenology.2007.04.023

KRISHNAKUMAR, K., V. PRABHAKARAN, C. CHANDRAHASAN, E. T. NAPOLEON (2008): Foetal maceration due to uterine torsion in a cross bred cow. Tamilnadu Journal Veterinary \& Animal Science 4, 203-204.

KUMAR, P., G. N. PUROHIT, J. S. MEHTA (2013a): Surgical management of a macerated bovine foetus. Rumin. Sci. 2, 107-108. 
M. Dolník et al.: Hysterotomy of a dairy cow with long-time macerated foetus

KUMAR, P., A. SHARMA, M. SINGH, P. SOOD, J. AGARWAL (2013b): Dystocia due to emphysematous fetus and fetal maldisposition in a buffalo. Buffalo Bull. 32, 160-161.

KUMARESAN, A., S. CHAND, S. SURESH, K. T. MOHANTY, S. PRASAD, S. S. LAYEK, K. BEHERA (2013): Effect of estradiol and cloprostenol combination therapy on expulsion of mummified foetus and subsequent fertility in four crossbred cows. Vet. Res. Forum 4, 85-89.

LEFEBVRE, C. R., E. SAINT-HILAIRE, I. MORIN, B. G. COUTO, D. FRANCOZ, M. BABKINE (2009): Retrospective case study of fetal mummification in cows that did not respond to prostaglandin F2 $\alpha$ treatment. Can. Vet. J. 50, 71-76.

MAHESH, R., G. KAMALAKAR, J. DEVARATHNAM, D. V. PRASAD, N. SUMIRAN, S. V. R. KUMAR (2015): Surgical management of dystocia due to incomplete cervical dilatation in a cow - a case study. Livestock Sci. 6, 77-79.

NEWMAN, D. K., E. D. ANDERSON (2005): Cesarean section in cows. Vet. Clin. Food Anim. 21, 73-100.

DOI: $10.1016 /$ j.cvfa.2004.12.001

PRAKASH, S., M. SELVARAJU, K. RAVIKUMAR, S. MANOKARAN, M. PALANISAMY (2016): Hysterotomy through colpotomy combined with cervicotomy for the treatment of foetal maceration in a cattle. Indian J. Anim. Reprod. 38, 60-61.

PRAVEEN, R. M., G. V. NAIDU (2015): Transrectal ultrasonographic monitoring of fetal maceration in a buffalo heifer -a case report. Int. J. Agric. Sci. 3, 41-43.

PUROHIT, N. G. (2012): Perspectives of fetal dystocia in cattle and buffalo. Vet. Sci. Dev. 2, 31-42. DOI: $10.4081 / \mathrm{vsd} .2012 . \mathrm{e} 8$

PUROHIT, N. G., M. GAUR (2011): Etiology, antenatal diagnosis and therapy of fetal complications of gestation of large and small domestic ruminants. Theriogenology 1, 43-62.

RAUTELA, R., D. K. YADAV, R. KATIYAR, S. K. SINGH, G. K. DAS, H. KUMAR (2016): Fetal maceration in goat: a case report. Int. J. Sci. Environ. Technol. 5, 2323-2326.

SCHÖNFELDER, M. A., A. SOBIRAJ (2006): Caesarean section and ovariohysterectomy after severe uterine torsion in four cows. Vet. Surg. 35, 206-210.

DOI: $10.1111 /$ j.1532-950X.2006.00133.x

SCHULTZ, G. L., W. J. TYLER, D. H. MOLL, M. G. CONSTANTINESCU (2008): Surgical approaches for caesarean section in cattle. Can. Vet. J. 49, 565-568.

WERMUNT, J. J. (2008): The Caesarean operation in cattle: a review. Iran J. Vet. Surg. 2, 82100.

Received: 10 April 2018

Accepted: 15 May 2019

Vet. arhiv 89 (6), 903-912, 2019 
DOLNÍK, M., M. KADAŠI, J.POŠIVÁK, M.TÓTH,P. MUDROŇ: Histerektomija mliječne krave s produljenom maceracijom ploda - prikaz slučaja. Vet. arhiv 89, 903-912, 2019.

\section{SAŽETAK}

Istražena je simentalska mliječna krava, u dobi od sedam godina, kod koje je u anamnezi istaknut iscjedak neugodna mirisa iz stidnice. Za vrijeme posljednjeg teljenja plod je uginuo u maternici i djelomično je uklonjen, dok su preostali njegovi dijelovi ostali u maternici sljedećih 14 mjeseci. Ginekološkim pregledom potvrđen je otvoren cerviks. Transrektalnom palpacijom i ultrazvukom otkriveno je opsežno proširenje, zadebljanje i napetost maternice te prisutnost raspadnutih dijelova ploda. Pokušaj vađenja ploda injekcijom prostaglandina bio je neuspješan stoga se histerektomija radila nisko na lijevom boku pod kranijalnom epiduralnom anestezijom i lokalnom infiltrirajućom anestezijom. Uklonjene su kosti ploda kao i preostali patološki sadržaj. Nakon zahvata, krava je dobila na tjelesnoj masi te je mogla biti upućena u klaonicu sa svrhom ekonomskog iskorištenja. Zaključeno je da histerektomija na lijevom boku može biti korisna pri uklanjanju maceriranih plodova kod krava.

Ključne riječi: mliječne krave; histerektomija; kirurški pristup; maceracija 